\title{
THE EFFECT OF MUSLIM PRODUCTS AS AN ISLAMIC RETAIL STORE ATTRIBUTE: A STUDY ON MUSLIM CONSUMER PATRONAGE BEHAVIOUR IN MALAYSIA
}

\author{
WAIDA IRANI MOHD FAUZI \\ SANY SANURI MOHD MOKHTAR \\ RUSHAMI ZIEN YUSOFF \\ School of Busniness Management \\ Universiti Utara Malaysia
}

\begin{abstract}
As Malaysian Muslim consumers are more concerned about religious teachings, the doubt about the halalalness of the ingredients, processing and handling of the products has attracted Muslim consumers' attention. Recently, Muslims are not only concerned about halal but the issue of "halalal tayibbah" has obtained great attention. In order to verify the "halalal tayibbah" concept, the acceptance of Muslim-made products is increasing in the market. With the spirit of helping the economy of the ummah, Muslim consumers tend to give their support to Muslim products. With a high demand for Muslim products, an initiative to introduce an Islamic-focused retail store has shown significant growth. Essentially, the store will provide a range of Muslim products as a substitute for previous brands. With regard to this phenomenon, the present study investigates the effect of Muslim products in an Islamic retail store on Muslim consumer-patronage behaviour. In order to get feedback, self-administered questionnaires were distributed to 384 patrons of Islamic retail stores in the northern region of Malaysia. The result of the partial least square analysis concluded that the provision of Muslim products has a significant impact on the patronagebehaviour of Muslim consumers. By buying Muslim products, Muslim consumers feel more confident that they are buying products that are religiously allowable and it prompts Muslim consumers' buying-decisions in patronizing a store.
\end{abstract}

Keywords: Muslim product. Muslim and patronage behaviour. 


\section{Introduction}

Recently consumers, specifically Muslims, may have various reasons for consuming and purchasing Muslim products. Some of the reasons are: feeling more confident in terms of the product's halal status, supporting the economy of the ummah, and the blessing of barakah. With high consciousness of the halal status and the various controversial issues regarding halal products, the acceptance of Muslim products is encouraging (Ozge-Ozgen, \& Kurt, 2013). Providing Muslim products in certain retail outlets seems to be part of an effort that is helping Muslim consumers to obtain Muslim products. Muslim products are assumed to be halal by default due to the Muslim producers, who have to comply with the Islamic manufacturing practices. Muslim consumers have high Islamic sensitivities and the products therefore adhere to Islamic laws.

In addition, the phenomenon is encouraged by fatwa declarations related to controversial issues such as boycotting various international brands due to tensions in the Middle East (Hutton, 2003; Murphy, 2003).To avoid or prohibit boycotting brands, sensitive Muslims try to find solutions through Muslim products. The changing behaviour of specifically sensitive Muslims may provide opportunities for Islamic business concepts. Besides providing a variety of substitutes for international brands produced by Muslim producers, these stores provide halal solutions for consumers. As religion is important to Muslim communities, practitioners and scholars tend to consider a religious stance in marketing areas. Marketers have started to realize the potential of appealing to Muslim consumers and followers of the Islamic religion. This paper intends to offer some insight into the issue of achieving the objectives of examining the influence of Muslim products on Islamic retail patrons in Malaysia. Previous studies have studied product evaluation in conventional perspectives, nevertheless, a few studies have looked further by investigating products from an Islamic viewpoint or Muslim-consumer perspectives in evaluating store patronage.

\section{Literature Review}

\section{Patronage Behaviour}

Patronage behaviour is the core objective of the retail business; it becomes the key to success for any particular retail business. Many 
definitions have been developed to explain patronage behaviour regarding particular stores. It can be defined as the store choice of a consumer based on a set of evaluative criteria and store loyalty to specific stores. In early research in this area, patronage behaviour refers to repeat purchases, commitment, and customers that are influenced by strong preferences to purchase at a particular store. This behaviour will result in loyalty (Spigell \& Sewall, 1987).

The same definition is addressed by(1993), where patronage behaviour refers to repeat purchases of the same product or any other products. A loyal customer will give priority to a particular store compared to other stores, and this will continue on a long-term basis. Moreover, other studies have defined store loyalty, or patronage behaviour, based on the revisiting behaviour of the customer (Dick \& Basu, 1994). For the purpose of this study, the operational definition is considered as repeat purchases in a particular store as compared to other stores on a long-term basis (Dick \& Basu, 1994).

\section{Muslim Products}

By definition a Muslim product refers to a product that must comply with the "halalal tayibbah" concept; guided by Islamic law, does not contain unpermitted elements originating from a forbidden substance, material or animal; is processed using equipment that is clean from impurities, and processed in an area reserved for halal and haram products (Kocturk, 2002). The product is produced by a Muslim producer following Syariah compliance and guidelines (Alserhan, 2010). It does not only have a halal certificate, but must be halal and pure (halalal tayyibbah) and comply with Islamic manufacturing practices.

\section{Muslim Products and Patronage Behaviour}

Products have a positive effect on people's patronage behaviour. According to many studies, products are an important aspect in attracting customers to patronize a store (Mitchell \& Kiral, 1998; Morschett, Swoboda, \& Foscht, 2005; Oppewal \& Koelemeijer, 2005). Previous studies have found that people are concerned with the quality of a product, product varieties in the store and brand names (Mitchell, 2001). However, there are also other product criteria used by religious people and this will affect their patronage behaviour (Rahadian, 2008). 
Previous studies have found that the distinctive behaviour of Muslims is due to their adherence to Islamic doctrines (Muhamad \& Mizerski, 2010; Regnerus \& Smith, 2005). Their shopping styles, ethical beliefs as consumers and their sensitivity towards offensive advertising are different from other religious groups (Essoo \& Dibb, 2004; Fam, Waller, \& Erdogan, 2004). Muslim consumers may have different evaluations in product selection with regards to their beliefs in terms of religious rules and laws. Some marketing research has found that Muslim consumers have an orientation to purchase Muslim-made products (Jeannot Abdul Karim, Sofiah Abdul Rahman, \& Zailin Zainal Ariffin, 2011) instead of any other product. The argument is also supported by Mokhlis (2008) and Razli (2004) who found that a strong preference to buy Muslim products is reported to be high among Muslim consumers. Some of them have prefer Islamic brands, which are guided by syariah principles and originate from an Islamic country (Alserhan, 2010).

With the high awareness of halal issue, the acceptance of Muslim products has become an important evaluation that influences store patronage behavior among Muslim consumers. By consuming Muslim products, consumers feel more confident as the product will fulfill the halalal tayyibbah concept as prescribed in the Al-Quran in surah Al-Baqarah (2:168 and 2:172).

"O ye people! Eat what is on earth, lawful (halal) and good (tayyib)...

(Al-Baqarah, 2:168)

"O you who believe! Eat of the good things that we have provided to you, and be grateful of God, if it is He ye worship. He hath only forbidden you dead meat, and blood, and the flesh of swine, and that on which any other name hath been invoked besides that of God."

(Al-Baqarah, 2:172)

Indirectly, if a Muslim product is believed to be generated from more trusted sources, people can reduce their doubts in consuming the product. As Muslim consumers, it is a part of their religious obligation to find Muslim products, and must shy away from products that are doubtful. 
The changing behaviour of Muslim consumers regarding halal product preference will affect Muslim product acceptance in the marketplace. Some research has indicated that Muslim products have become one of the attributes that describe the image of halal in certain retail stores. Moreover, Muslim products form a basic structure in establishing individual halal standards in the buying process (Abang Sulaiman Abang Saleh, 2010). Past studies on store attributes have focussed on products in terms of the quality, variety and other criteria related to store patronage. Based on the arguments stated in the literature, the present study hypothesises that:

H1: Muslim products will have a significant influence on Muslim consumer patronage behaviour.

\section{Research Methodology}

Data was collected in the northern region of Malaysia by using cluster sampling. A total of 384 respondents participated in this survey through the mall intercept approach. The target population was Muslim consumers who patronize selected retail stores in the northern region. Muslim consumers were chosen because they have become a dominant market with a population of 2.6 million and this number is projected to increase to 6.2 million in 2013 (Islam, 2009). The northern region was chosen as the specific area due to the reason that there are a number of small retail stores (including Islamic retail stores) in this area and the number is greater compared to the other states in Malaysia. In addition, the area has 65.1\% Malay Muslim consumers compared to the other religions.

The study used a probability sampling called cluster sample, which allowed for equal representation of respondents in the store in the selected areas and locations but this type of sampling did not consider population frame. The first step of the study considered the area of the study which was the northern region. In the next step the study created a directory of the retail store in that specified area of study. In order to help identify the population frame of the small retail store, the study recruited a research assistant to find and make a list of the store in three states (Kedah, Pulau Pinang, Perlis), so that the appropriate number of the stores could be identify accurately.

The respondents were asked to complete six-page questionnaires regarding Muslim store attributes, as well as several items in the demographic section. The completed questionnaires were deemed 
usable for further statistical analysis. The items for store attributes and patronage behaviour were adapted from various authors such as Lee, Fairhurst \& Dillard (2002), Jantan \& Kamaruddin (1999), Eackman et al. (1999), Chowdhury \& Reardon (1998) and Hansen \& Deutscher (1977). The additional store attribute items related to Muslim consumers were adapted from Gayatri (2008) and Mort \& Hume.

\section{Data Analysis}

The data of the study was analyzed by using smart PLS 2.0. The analysis involved two stages: firstly an assessment of the reliability and validity of the measurement model and secondly an assessment of the structural model. The findings of the study are discussed in the following section.

\section{Findings}

\section{Internal Consistency or Reliability}

The findings of the study indicated values that meet the internal consistency and reliability criteria. To calculate the internal consistency and reliability of the measurement, the Cronbach Alpha value must exceed 0.70, and the study reported that the measurement model had satisfactory internal consistency reliability when the Cronbach Alpha (CA) of each construct exceeded the threshold value of 0.7582 and the composite reliability exceeded 0.8378 . Table 1 shows that the Cronbach Alpha results exceed 0.7 and the composite reliability is above 0.8 . According to the results, the items used to represent the construct have satisfactory internal consistency reliability.

Table 1

Internal Consistency or Reliability

\begin{tabular}{cccc}
\hline Constructs & Numbers of items & Composite Reliability & Cronbach Alpha \\
\hline PM & 5 & 0.8378 & 0.7582 \\
\hline
\end{tabular}

The measurement model's convergent validity was assessed by examining its average variance extracted (AVE) value. Convergent validity is adequate when constructs have an average variance extracted (AVE) value of at least 0.5 or more. Table 2 shows that all 
the items that measured Muslim products had value loading that was above 0.5 for the AVE (0.5081) and a composite reliability index of 0.7582 .

Table 2

The Convergent Validity Assessment Results

\begin{tabular}{lcccc}
\hline Model Construct & Measurement Items & Loadings & AVE & CR \\
\hline PM & b1 & 0.712 & 0.5081 & 0.8378 \\
& b2 & 0.704 & & \\
b3 & 0.721 & & \\
b6 & 0.733 & & \\
b7 & 0.693 & & \\
\hline
\end{tabular}

Next, the structural model was used to test the hypothesis of the present study which stated that Muslim products are positively associated with Muslim consumer patronage behaviour. The analysis of the structural model showed the relationship of the hypothesis was supported. The result proved that there is a statistically significant relationship between Muslim products and the patronage behaviour of Muslim consumers in Islamic retail stores. The relationship of the two variables was relatively significant $(\beta=0.165, t$-value $=2.2416, p$ $<0.01)$. The findings of the study may lead to certain conclusions, discussion and valuable recommendations for practitioners.

Table 5.3

Hypothesis Testing Relationship

\begin{tabular}{ccccccc}
\hline Hypothesis & & Beta & $\begin{array}{c}\text { Standard } \\
\text { Deviation } \\
\text { (STDEV) }\end{array}$ & $\begin{array}{c}\text { T value }(\mathrm{IO} / \\
\text { STERR } \mid)\end{array}$ & Decision \\
\hline H1 & PM & PB & 0.165 & 0.0738 & $2.2416^{* *}$ & supported \\
\hline
\end{tabular}

${ }^{*} \mathrm{p}<0.05,{ }^{* *} \mathrm{p}<0.01$

\section{Conclusion and Recommendations}

The findings of the study indicate that Muslim consumers' acceptance of Muslim products is significant with a t-value of 2.2416 and therefore it is one of the most important criteria in patronage behaviour. 
However the findings contradict previous studies in conventional areas, which found that people are concerned about the quality of a product, product varieties in the store and product brand names (Mitchell, 2001; Theodoridis \& Chatzipanagiotou, 2009; Verhallen \& de Nooij, 1982; Yavas, 2003).

The fact that the findings contradict previous research findings might be because support for Muslim products has increased among Muslim consumers. With issues such as "Muslims in Gaza", Muslim consumers have shown their social responsibility in supporting the economics of the ummah and the responsibility to buy local products has increased (Al-Ajmi, Hussain, \& Al-Saleh, 2009; Razli, 2004). They believe that it is a part of Muslim responsibility to support other Islamic businesses. In several cases, local products have been produced to serve as alternatives to the boycotted products. In a similar call for an economic jihad, there has been an increasing interest among concerned Muslim consumers to support Muslim-owned (e.g. Sandicki), and Muslim-friendly businesses (e.g. Best Buy).

Accordingly, Muslim products are more preferable in the market compared to other conventional products as Muslim consumers are always searching for lawful (halal) and wholesome (tayyib) products as stated in the Al-Quran in surah Al-Baqarah (2:168):

\section{"O ye people! Eat what is on earth, lawful (halal) and good (tayyib)...}

(Al-Baqarah, 2:168)

It is a part of their "ibadah" to get pleasure from Allah; Muslim products are considered as halalal tayibba products as they comply with several factors such as the source of raw materials and the biological and chemical safety. Essentially, the product is only considered as the best product when it comes from the right source, is useful, clean, wholesome and beneficial morally and ethically, and is not in conflict with what is forbidden by Islam in every sense (Kocturk, 2002; Power, 2009).

The findings of the study have great value for marketers because they will help in improving their strategy in targeting Muslim consumers and engaging Islamic markets. By having a selection of products made by Muslim producers, there is a good opportunity for Muslim 
retailers to expand their business and search for Muslim products to sell in their stores. All manufacturers who are Islamic Manufacturing Practice (IMP) certified must be given equal opportunity to market their products to be assured that halal and the tayyiban aspect are well addressed as a part of their "fardu kifayah" in serving the Muslim community. In summary, the findings of the study have concluded that Muslim products have a significant positive effect on the patronage behaviour of Muslim consumers. Thus, for retailers who target their businesses at Muslims, it is their responsibility to provide and search for substitute products or brands which are manufactured by Muslim producers. This consideration can create a great opportunity for the retailers to serve Muslim consumers, specifically in the Malaysian market.

\section{References}

Abang Sulaiman Abang Saleh, Norazah Mohd Suki., \& Stephen Laison Sondoh. (2010). Attributes in halal standard:What is in the mind of consumers? Retrieved from http://www.wbiconpro. com/505-Abang.pdf

Ahmad, M., \& Kadir, S. A. (2013). Characteristics of entrepreneurs and the practice of Islamic values in influencing the success of small medium enterprises in Kelantan and Selangor. Journal of Social \& Development Sciences, 4(5), 229-235.

Al-Ajmi, J., Hussain, H. A., \& Al-Saleh, N. (2009). Clients of conventional and Islamic banks in Bahrain: How they choose which bank to patronize. International Journal of Social Economics, 36(11), 1086-1112.

Alserhan, B. (2010). On Islamic branding: Brands as good deeds. Journal of Islamic Marketing, 1(2), 101-106.

Chowdhury, J., \& Reardon, J. (1998). Alternative modes of measuring store image: An empirical assessment of structured versus unstructured measures. Journal of Marketing Theory \& Practice, $6(2), 72-86$.

Dick, A., \& Basu, K. (1994). Customer loyalty: Toward an integrated conceptual framework. Journal of the Academy of Marketing Science, 22(2), 99-113.

Essoo, N., \& Dibb, S. (2004). Religious influences on shopping behaviour: An exploratory study. Journal of Marketing Management, 20(7), 683-712.

Fam, K. S., Waller, D. S., \& Erdogan, B. Z. (2004). The influence of religion on attitudes towards the advertising of controversial products. European Journal of Marketing, 38(5/6), 537-555. 
Gayatri, G. (2008). Re-specifying a service quality instrument to an Islamic perspective. Australian National University.

Hansen, R., \& Deutscher, T. (1977). An empirical investigation of attribute importance in retail store selection. Journal of Retailing, 53(4), 59-72.

Islam, W. (2009). Symposium summary. Advances in Consumer Research, 36.

Jeannot Abdul Karim, Sofiah Abdul Rahman, \& Zailin Zainal Ariffin. (2011). Do Muslims purchase Muslim products? Muslim centricness: An exploratory study. Paper presented at the 2011 International Conference on E-business, Management and Economics IPEDR Vol.25 (2011) @ (2011) IACSIT Press, Singapore.

Ozge-Ozgen., \& Kurt, S. D. (2013). Purchasing behavior of Islamic brands: An experimental research. Paper presented at the EMAC Conference, Istanbul.

Kocturk, T. (2002). Food rules in the Koran. Scandinavian Journal of Food \& Nutrition, 46(3), 137-139.

Mitchell, V. W. (2001). Re-conceptualizing consumer store image processing using perceived risk. Journal of Business Research, 54(2), 167-172.

Mitchell, V. W., \& Kiral, R. (1998). Primary and secondary store-loyal customer perceptions of grocery retailers. British Food Journal, 100(7), 312-319.

Mokhlis, S. (2008). Consumer religiosity and the importance of store attributes. The Journal of Human Resource and Adult Learning, $4(2), 122-133$.

Morschett, D., Swoboda, B., \& Foscht, T. (2005). Perception of store attributes and overall attitude towards grocery retailers: The role of shopping motives. The International Review of Retail, Distribution and Consumer Research, 15(4), 423-447.

Mort, G., \& Hume, M. (2010). Understanding service quality from the Islamic customer perspective Gita Gayatri, Chris Chan. Australia: Australian National University.

Muhamad, N., \& Mizerski, D. (2010). The constructs mediating religions' influence on buyers and consumers. JIMA, 1, 2.

Oppewal, H., \& Koelemeijer, K. (2005). More choice is better: Effects of assortment size and composition on assortment evaluation. International Journal of Research in Marketing, 22(1), 45-60.

Osman, M. (1993). A conceptual model of retail image influences on loyalty patronage behaviour. The International Review of Retail, Distribution and Consumer Research, 3(2), 133-148.

Power, C. (2009). Halal: Buying Muslim. Time. 
Rahadian, M. (2008). The effects of decision-making styles on consumers' perceptions: The moderating effects of religiosity and type of products. German: VDM Verlag.

Razli, N. M. A. (2004). Consumer Ethnocentrism: The relationship with domestic products evaluation and buying preferences. IJMS, 11(Special issue), 29-44.

Regnerus, M. D., \& Smith, C. (2005). Selection effects in studies of religious influence. Review of Religious Research, 23-50.

Theodoridis, P. K., \& Chatzipanagiotou, K. C. (2009). Store image attributes and customer satisfaction across different customer profiles within the supermarket sector in Greece. European Journal of Marketing, 43(5/6), 708-734.

Verhallen, T. M. M., \& de Nooij, G. J. (1982). Retail attribute sensitivity and shopping patronage. Journal of Economic Psychology, 2(1), 39-55.

Yavas, U. (2003). A multi-attribute approach to understanding shopper segments. International Journal of Retail $\mathcal{E}$ Distribution Management, 31(11), 541-548. 